Defoliation and Mortality in Connecticut Forests

By George R. Stephens

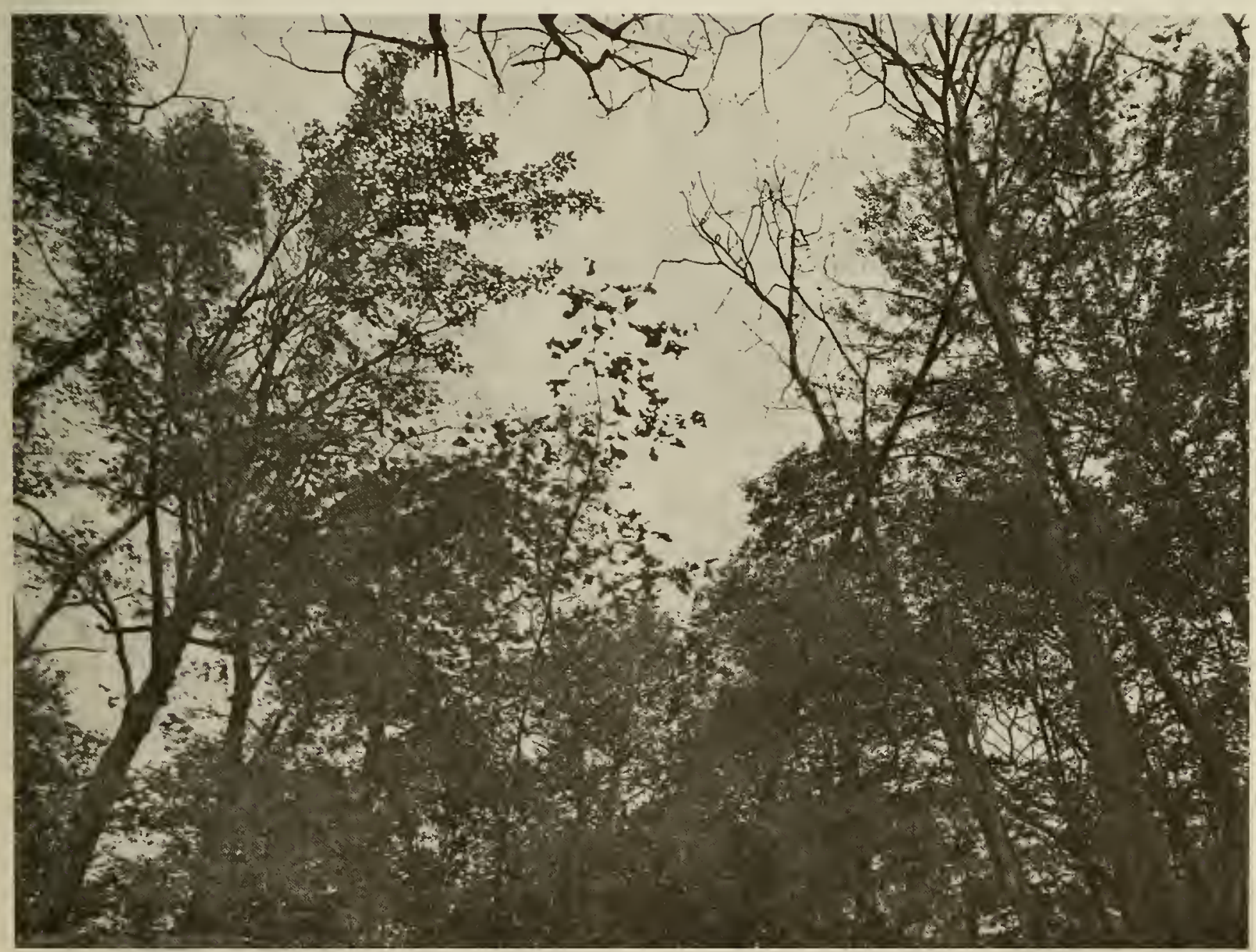

BULLETIN 796 - THE CONNECTICUT AGRICULTURAL EXPERIMENT STATION NEW HAVEN • APRIL 1981 


\section{Summary}

Deciduous hardwoods comprise most of Connecticut's forest. During the past three decades ever increasing portions of the forest have been periodically defoliated, primarily by gypsy moth, al though other forest defoliators have also been abundant.

Periodic observations of persistence, ingrowth and mortality of trees on nine tracts scattered across connecticut were combined with observations of defoliations in order to determine the effect of defoliation on tree mortality. Seven of the tracts were evenaged and less than 100 years old. Only two tracts contained conifers.

on undefoliated, evenaged stands under 50 years old mortality during a decade averaged about 3 percent annually. on older stands, in a recent time, average annual mortality was lower, about 2 percent. Mortality increased with the population of trees and was higher on dry than on moist sites.

A single defoliation in a decade had no effect on mortality. However, within a decade repeated defoliation was followed by increased tree mortality, but average annual mortality increased by only half, compared to undefoliated stands. Repeated defoliation in a subsequent decade was also followed by increased mortality, but mortality was generally less in the later than in the earlier decade.

Annual observations of mortality in one tract showed that mortality increased as defoliation of the canopy increased. Greatest mortality occurred one or two years after severe defoliation. The greatest average annual mortality, 3.5 percent, occurred the year following two successive defoliations.

During a decade without defoliation loss of basal area in stands under 50 years old averaged about 1 percent annually. A single defoliation did not affect loss of basal area during a decade. Losses nearly doubled after repeated defoliation, especially on the moister sites. Repeated defoliation in a subse- quent decade was also accompanied by increased basal area loss. The losses were slightly less than in the previous decade and seemed less influenced by soil moisture.

Repeated defoliation was followed by increased losses among canopy trees. Mortality increased as the proportion of canopy defoliated increased. Much of the loss occurred among pole-sized trees.

Mortality varied among species groups. In undefoliated stands mortality of oak was generally higher than mortality of maple or birch. After repeated defoliation mortality of all species groups tended to increase. Loss of basal area among oaks indicated that large oaks died, whereas relatively small maples and birches died. Increasing canopy defoliation was accompanied by increased mortality and loss of basal area of oak, but not of maple. Mortality of white and chestnut oak was greater than red, black or scarlet oak.

Mortality in Connecticut forests was compared to mortality in other places. The results are similar; repeated defoliation is followed by increased mortality, especially among oaks. There is no direct evidence that defoliation causes mortality; it apparently renders trees susceptible to other killing agents. Shoestring fungus and twolined chestnut borer have repeatedly been associated with dead or dying oak after defoliation.

With repeated defoliation oaks will suffer greater mortality than other species and mortality will likely be greater where the proportion of oak in the forest is greater. Species less susceptible to defoliation and mortality, such as maple and birch, will increase. Elimination of susceptible trees in one decade may decrease mortality during a subsequent decade with defoliation. Al though forest composition may be altered, it seems unlikely that defoliation will completely destroy the forest. 


\title{
DEFOLIATION AND MORTALITY IN CONNECTICUT FORESTS
}

\author{
By George R. Stephens
}

Again severe defoliation of portions of Connnecticut's hardwood forest by caterpillars and the prospect for continued defoliation in many areas threatens the forest. Many will ask what effect the defoliation will have. Ten years ago I summarized available information relating defoliation to tree mortality (Stephens 1971). I repeat that information and add new observations in this Bulletin which will describe mortality in defoliated forests in Connecticut, present differences in mortality among species groups, and relate mortality in connecticut forests to that in similar forests of other places.

\section{The Forests}

The observations reported here were obtained by sampling nine forest tracts scattered across Connecticut. Four, the Meshomasic series, are in the Meshomasic and Cockaponset State Forests of Middlesex County and have been described (Stephens and Waggoner 1980). Four others, the New series, are more widely scattered: Gay City State Park, on the border of Hartford and Tolland Counties; Catlin Wood and Norfolk in Litchfield County: Natchaug State Forest in Windham county. The New series has also been described (Stephens and Hill 1971) and additional information will appear in Bulletin 799 (Stephens and Hill 1981). The ninth area, Haddam, is an isolated segment of the Cockaponset State Forest near the border of the towns of Durham and Haddam in Middlesex county.

The stands in the Meshomasic series are essentially evenaged, presently 80 to 95 years old. In the New series, Gay City and Natchaug are also evenaged but 20 to 30 years younger than the Meshomasic series. Catlin Wood and Norfolk are older and unevenaged. In Catlin Wood the oldest trees approach 200 years and trees of all ages are present. Norfolk has two age groups; many of the 1 arger trees are 90 to 100 years, and the younger group is about 70 years old. Trees in the Haddam tract are also approximately evenaged and about 20 years younger than the Meshomasic series.

All stems greater than 0.5 inch diameter breast high (dbh) ( 4.5 feet above ground) were located, identified and described on nearly 10 undisturbed acres of the Meshomasic series. Enumerations in 1927, 1937, 1957. 1967, and 1977 provided an accurate record of trees persisting; of ingrowth, that is, stems newly appearing; and of mortality, stems dying. In the New series similar enumerations were made in 1959, 1970 and 1980 on nearly 2 acres. In the Haddam tract, three acres were examined annually during 1971-74; a fourth acre was added to the sample during 1972-74. Although the total sample area was about 16 acres, sample transects 16.5 feet wide running uphill and down represent a full range of Connecticut conditions. For the Meshomasic and New series estimates of annual defoliation were obtained from unpublished annual defoliation maps in the files of the State Entomologist, New Haven. These maps, prepared from a combination of ground and aerial reconnaisance, describe broad defoliation categories for the forest, but not individual 
species. On the Haddam tract the percent of defoliation of each tree crown in the sample was estimated annually during, 1971-74.

The tracts varied in elevation, topography, soils and drainage; for convenience they have been subdivided into four sites based on internal soil drainage. The wettest site (1) is called muck, a wet, swampy soil sometimes covered with standing water. The moist site (2) included the very poorly drained, the poorly drained and the somewhat poorly drained soils common along streams or in valley bottoms. Medium moist (3) included the moderately well drained and well drained soils. These soils (3) generally occur in midslope and normally support good tree growth. The dry site (4) included the somewhat excessively drained and the excessively drained soils. This site (4) occurs on the ridgetops and upper slopes only thinly mantled with soil.

Seven of the tracts contained mostly deciduous hardwoods. The distribution of species varied with tract and site, but 30 major tree species and 7 minor species, small trees or large shrubs, were represented. Among the major species oaks, maples and birches were abundant. Only Catlin Wood and Norfolk contained appreciable numbers of conifers, mostly hemlock.

\section{The Problem}

Chronic defoliation persists in the forest at all times and the list of defoliators is long. Such defoliation is usually slight and goes unnoticed. However, the massive defoliation brought about by sudden large increases in insect populations, especially voracious caterpillars, is both spectacular and al arming. Gypsy moth continues preeminent, but elm spanworm, fall and spring cankerworms, leaftiers and others have been abundant at various times. From the standpoint of effect on the trees, however, it is likely that time of defoliation and amount of foliage removed are important; identity of the defoliators is secondary. Accordingly, in this Bulletin defoliation, not defoliator, is emphasized.

\section{Normal Mortality}

Death of trees in the forest is a continuing natural process. Competition among trees and shrubs for light, water, rutrients, and growing space causes survival of some and death of others. Endemic diseases and insects exert a steady pressure. Weather phenomena such as wind, ice, snow, and lightning exact their small toll. In evenaged forests, especially, there is a decline in numbers of stems from the young to the mature forest.

For example, in a young, evenaged forest the population may be several thousand stems per acre. Losses over a decade are great. As a forest matures, losses decrease. Finally, in an old, unevenaged forest there is slow turnover among stems; mortality and ingrowth are nearly balanced, and the population remains nearly constant. This change in population and mortality can be seen in observations from the Meshomasic series during 1927-77 (Fig. 1). The $r$ ise in number of stems during 1967-77 is 1 ikely a temporary event caused by the loss of a few large trees during 1957-67 and their subsequent replacement by many small stems.

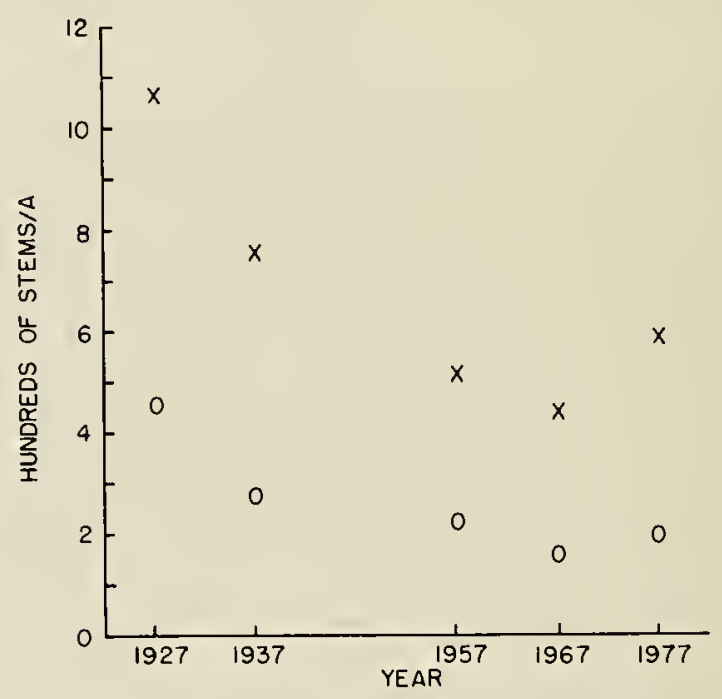

Fig. 1. Population change in the Meshomasic series during 1927-77 for major species $(X)$ and minor species $(O)$.

Mortality on undefoliated, undisturbed stands is portrayed in Fig. 2. Major and minor species compete with each other and both died, but only mortality of the major tree species will be considered. The upper portion of Fig. 2 compares mortality of major species on the Meshomasic series during 1927-37 to the total population of major and minor species present in 1927. During this decade the stands were relatively young and severe defoliation was never mentioned by any observer. The numbers $1,2,3$, and 4 are the sites from wettest to driest, and the line is the linear regression, or straight-line trend, that best fits the observations. As population increases so does mortality. Note, 
however, that mortality on the moister sites generally lies below the trend line whereas it lies above on the drier sites. on all sites except muck, average annual mortality of major species was slightly more than 3 percent. The highest, 3.5 percent, occurred on the medium moist site.

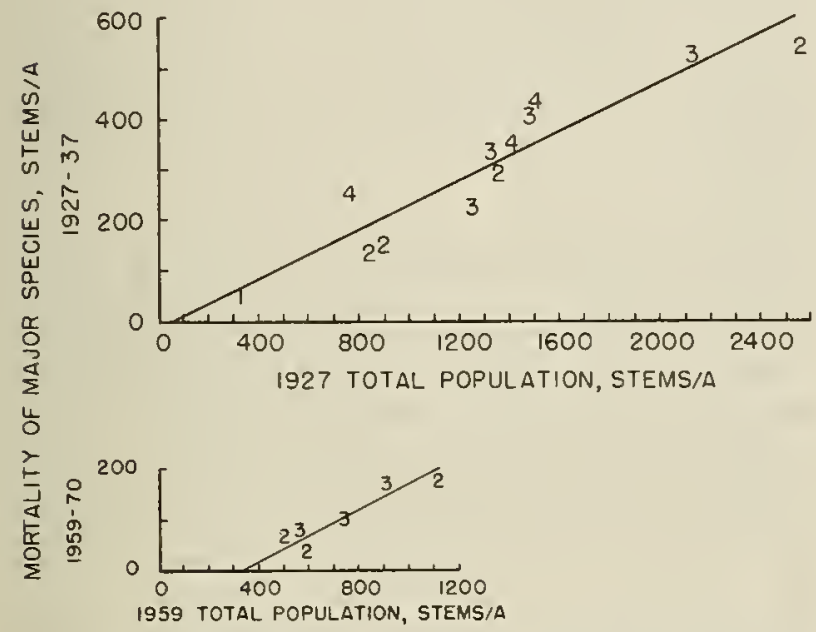

Fig. 2. Periodic mortal ity of major species in tracts without major defoliation. The numbers are the sites: muck (1), moist (2), medium moist (3) and dry (4). The line is the straight line that best fits the observations. Upper. Meshomasic series, 1927-37. Lower. Catl in Wood, Norfolk and Natchaug of the New series, 1959-70.

The lower portion of Fig. 2 portrays mortality in three undefoliated tracts of the New series in a more recent time, 1959-70. There were no very wet or dry sites as on the Meshomasic series. Although Catlin Wood had been more than half defoliated in 1956 , before the enumeration began, its mortality during 1959-70 did not differ from undefoliated Norfolk or Natchaug. This suggests that the effect of a prior single defoliation is short-lived. The trend line fits the observations well and, despite differences in age of the stands, it is similar to that of the Meshomasic series in an earlier decade. However, for a given population, mortality on the New Series during 1959-70 was less than on the Meshomasic series during 1927-37. Annual mortality of major species averaged less than 2 percent. Mortality was higher on medium moist than on moist sites. Thus, even in different decades mortality of major species was similar on undefoliated stands, increasing with population and decreasing with increasing age. Average annual mortality ranged from slightly less than 2 to slightly more than 3 percent over both series.

Because mortality apparently is influenced by age, the trend of mortality with population size in a recent time without defoliation (New series, 1959-70) will be used to compare mortality on defoliated stands.

\section{Mortality in Defoliated Stands}

Does tree mortality on defoliated stands differ from that on undefoliated stands? During 1957-67 all tracts on the Meshomasic series were defoliated (Table 1). Cox, Reeves and Cabin were each defoliated three times during 1961-63. Turkey Hill was defoliated between 25 and 75 percent in 1964 .

Table 1. Estimated canopy defoliation' of Meshomasic and New series tracts.

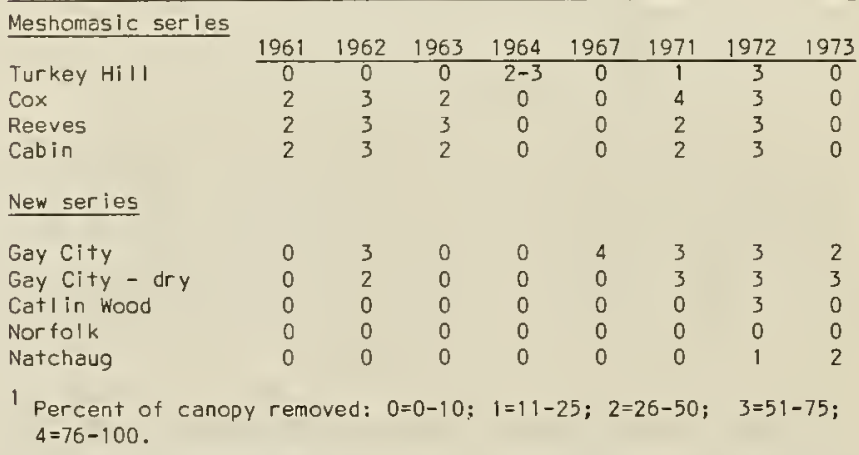

The upper portion of Fig. 3 depicts mortality of major species during 1957-67 on the Meshomasic series. As before, numbers designate site. Uncircled numbers are from oncedefoliated Turkey Hill. The uncircled numbers with high population are from a portion of Turkey Hill that burned in 1932 but has since regrown. Circled observations are the thrice-defoliated Cox, Reeves and Cabin tracts. The line is the trend line of mortality in the undefoliated New series, 1959-70 (Fig. 2, lower). Note that the mortality on once-defoliated Turkey Hill cannot be distinguished from the mortality in the undefoliated tracts of the New series. On the other hand, mortality in the thrice-defoliated tracts, especially on the drier sites, clearly lies above the line. Average annual mortality of major species was 2.7 percent on the unburned tracts. On the burned portion of Turkey Hill it was 3.6 percent. After defoliation mortality increased by nearly half 
compared to undefoliated tracts.

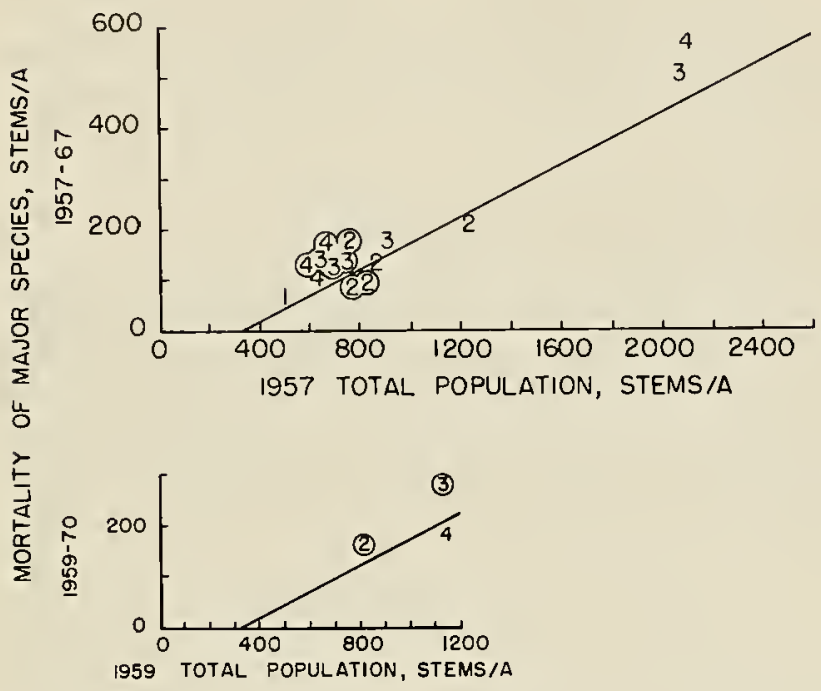

Fig. 3. Periodic mortality of major species in tracts with major defoliation. The sites are as in Fig. 2. The line is the mortality trend observed in 1959-70 in undefoliated tracts (Fig. 2, lower). Upper. Meshomasic series, 1957-67. Uncircled numbers are from Turkey Hill defoliated in 1964. Circled numbers are from Cox, Reeves and Cabin defoliated in 1961, 1962, and 1963. Lower. Gay City, 1959-70. Uncircled 4 is the dry site defo1 lated in 1962. Circled numbers are the moister sites defoliated in 1962 and 1967.

The lower portion of Fig. 3 shows observed mortality of major species during 1959-70 at Gay City of the New series. In 1962 defoliation removed less than half of the canopy on the dry ridgetop but more than half on the remainder of the tract. In 1967 the dry site was undefoliated while the remainder of tract was more than 75 percent defoliated. The uncircled 4 indicates mortality on the oncedefoliated dry site. The circled numbers are the twice-defoliated moister sites. As before the line is the mortality trend on undefoliated tracts of the New series, 1959-70 (Fig. 2, lower). Mortality on the once-defoliated dry site (4) lies below the trend in undefoliated tracts during 1959-70. Mortality on the twice-defoliated moist (2) and medium moist (3) sites lies above the trend and on the medium moist site is clearly greater. Average annual mortality of major species was 1.8 percent on the once-defoliated dry site but more than 3 percent on the twice-defoliated sites.

The upper portion of Fig. 4 shows the observed mortality of major species during 1967-77 on the Meshomasic series. All four tracts were defoliated twice in 1971-72 but in differing amounts (Table 1). The circled numbers show the mortality on Cox, heavily defoliated in 1971. The line is the trend of mortality on the undefoliated New series, 1959-70 (Fig. 2, lower). Again, the three sites with high population are from the burned portion of Turkey Hill. Mortality of heavily-defoliated Cox differed little from the other tracts. Generally all sites show increased mortality compared to tracts undefoliated in 1959-70. Mortality on Turkey Hill was higher than on the other Meshomasic tracts.

The lower portion of Fig. 4 portrays mortality of major species during 1970-80 on the New series. Catlin Wood was defoliated once in 1972. Natchaug was partially defoliated in 1972 and 1973. Gay City (circled numbers) was defoliated three times during 1971-73. On the dry site (4) more than half of the foliage was removed each year. Despite repeated defoliation at Gay City, only on the dry site (4) was mortality increased noticeably above the trend on undefoliated tracts during 1959-70. Average annual mortality of major species ranged from 1.3 to 2.5 percent.

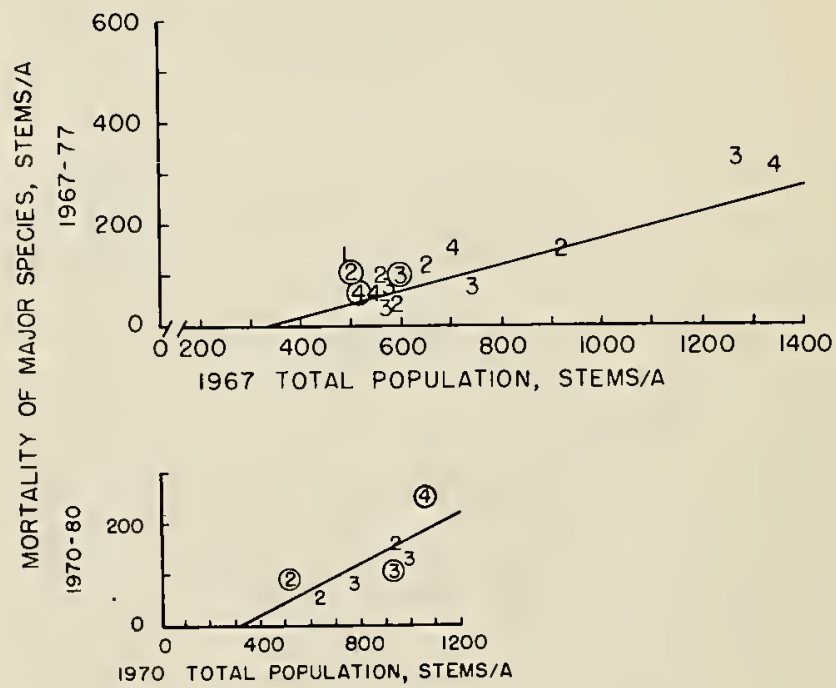

Fig. 4. Periodic mortality of major species in tracts with major defoliation. The sites are as in Fig. 2. The line is the mortality trend observed in 1959-70 in undefoliated tracts (Fig. 2, lower). Upper. Meshomasic series, 1967-77. All tracts were partially defoliated in 1971 and 1972. Cox (circled) was severely defoliated in 1971. Lower. New Series, 1970-80. Gay City (circled), defoliated 1971, 1972, 1973; Natchaug, I ightly defoliated 1972, 1973; Catl in Wood, defoliated 1972. 
In summary, observations taken at the beginning and end of a decade indicate that tree mortality occurs even on undefoliated stands, but it is slight. In young stands average annual mortality ranged from 2 to 4 percent for major species; in older stands, it was less than 2 percent. Mortality in a decade with a single defoliation did not differ from that without defoliation. Where there were two or more defoliations in a decade average annual mortality increased, ranging from 2 to 4 percent of major species but not more than a doubling. Mortality in stands defoliated during 1967-77 and 1970-80 was generally less than mortality in those same stands during 1957-67 and 1959-70. The lesser mortality in the more recent decade may indicate that heavy mortality in the earlier decade left fewer susceptible trees to die in the later decade. However, the more recent decade was moist, whereas the earlier was dry in comparison. The data do not permit a clear distinction between these two factors.

Annual Mortality

In all of the defoliated tracts reported so far the defoliation occurred near the midpoint of the observation interval. However. the average over the interval does not tell whether mortality was nearly the same each year during the interval or whether there were great fluctuations in mortality, especially during or soon after defoliation. Fortunately, some annual observations are avail able.

During 1971-74 at Haddan defoliation and mortality were observed annually. Four parallel transects, each a half-mile long and an eighth-mile apart, were examined. Portions of the tract were sprayed in 1971 and 1972 to prevent or reduce the amount of defoliation, thus providing a comparison of mortality in relatively undefoliated, partially defoliated, and heavily defoliated transects ( Table 2).

Some defoliation occurred on all lines in 1970, but it was not severe enough to be detected by an aerial survey. In 1971 line A was sprayed in early June to prevent defoliation and line $B$ was sprayed in mid-June to limit defoliation. Line $C$ remained unsprayed and was heavily defoliated. In 1972 lines A, $B$ and $C$ were sprayed in late May and early June to prevent defoliation. Line D remained unsprayed and was partially defoliated. Little defoliation occurred during 1973-74.

on line $A$, defoliated about a third in
Table 2. Annual canopy defoliation at Haddem during 1971-74.

\begin{tabular}{|c|c|}
\hline & Percent defoliation \\
\hline Line Species Group & $\begin{array}{lllll}1971 & 1972 & 1973 & 1974\end{array}$ \\
\hline
\end{tabular}

\begin{tabular}{|c|c|c|c|c|c|}
\hline \multirow[t]{4}{*}{ A } & Maple-Birch & 13 & 8 & 0 & 0 \\
\hline & Oak & 40 & 12 & 4 & 3 \\
\hline & Other species & 17 & 10 & 0 & $T$ \\
\hline & Al| species & 34 & 12 & 3 & ? \\
\hline \multirow[t]{4}{*}{ B } & Maple-Birch & 68 & 14 & 0 & 0 \\
\hline & Oek & 67 & 10 & 7 & 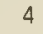 \\
\hline & Other species & 86 & 17 & 0 & \\
\hline & All species & 84 & 11 & 5 & \\
\hline \multirow[t]{4}{*}{$\mathrm{C}$} & Maple-Birch & 62 & 10 & $\mathrm{~T}$ & 0 \\
\hline & Oak & 94 & 17 & 13 & 6 \\
\hline & Other species & 84 & $1 \varepsilon$ & 2 & \\
\hline & All species & 90 & 16 & 11 & \\
\hline \multirow[t]{4}{*}{ D } & Meple-Birch & $(62)^{2}$ & 27 & 0 & 0 \\
\hline & Oak & (94) & 29 & 16 & \\
\hline & Other species & (84) & 50 & 8 & \\
\hline & All species & $(90)$ & 29 & 14 & 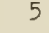 \\
\hline \multicolumn{6}{|c|}{$\begin{array}{l}1 \text { Less than } 1 \text { percent. } \\
2 \text { Line } D \text { not observed in } 1971 \text {, de fol iation } \\
\text { assumed equal to Line } C \text {. }\end{array}$} \\
\hline
\end{tabular}

1971, annual mortality during 1971-74 averaged 1.6 percent (Table 3). However, in 1972 mortality of major species was 2.3 percent. On line B, severely defoliated in 1971. annual mortality during 1971-74 averaged 2.0 percent, somewhat higher than on line A. Greatest mortality, 2.3 percent, occurred in 1974. On line C, nearly completely defoliated in 1971, average annual mortality was 2.4 percent. Line $D$ was not observed in 1971 but was assumed to have defoliation equal to that on line $C$. It was defoliated less than a third in 1972. Average annual mortality during $1971-74$ was also 2.4 percent; in 1973, however, it rose to $3.5 \mathrm{per}-$ cent.

Thus, mortality of the forest did increase soon after severe defoliation, but even over a brief span of three years, the average increased by only about half compared to similar stands with little defoliation. Discussion of whether mortality differed among species groups will be postponed until another measure of mortality, loss of basal area is examined.

\section{Loss of Basal Area}

The discussion of mortality so far concerns only numbers of stems. It fails to tell us whether dying trees were small or large. Basal area, the cross-sectional area of stems derived from dbh, can reveal 
Table 3. Annual mortality of major species at Haddam during 1971-74.

\begin{tabular}{|c|c|c|c|c|c|c|c|c|c|}
\hline Line & Species Group & Stems & $\begin{array}{l}\text { Perce } \\
72 \\
\text { asal A }\end{array}$ & $\begin{array}{l}\text { nt of } s \\
. \text { stems } \\
\end{array}$ & $\begin{array}{c}\text { pecies g } \\
1973 \\
\text { Basal A }\end{array}$ & $\begin{array}{l}\text { oup in } \\
\text { stems }\end{array}$ & $\begin{array}{l}\text { previous } \\
974 \\
\text { Basal A. }\end{array}$ & $\begin{array}{c}\text { year } \\
197 \\
\text { Stems } \\
\end{array}$ & $\begin{array}{l}2-74^{1} \\
\text { 3asal A. }\end{array}$ \\
\hline \multirow[t]{4}{*}{ A } & Maple-Birch & 2.4 & 1.7 & 1.6 & 0.6 & 1.8 & 1.7 & 2.0 & 1.3 \\
\hline & Oak & 2.9 & 0.8 & 0.7 & 0.01 & 0.7 & 0.4 & 1.5 & 0.4 \\
\hline & Other species & 2.9 & 1.4 & 1.4 & 0.0 & 1.5 & 2.0 & 2.0 & 1.1 \\
\hline & All species & 2.3 & 1.2 & 1.2 & 0.2 & 1.3 & 1.1 & 1.6 & 0.8 \\
\hline \multirow[t]{4}{*}{$B$} & Maple-Birch & 1.6 & 0.8 & 1.1 & 1.0 & 1.2 & 1.5 & 1.4 & 1.2 \\
\hline & Oak & 3.9 & 1.8 & 3.1 & 2.2 & 7.1 & 3.4 & 4.7 & 2.4 \\
\hline & other species & 1.0 & 0.1 & 1.8 & 6.8 & 2.4 & 0.5 & 2.0 & 2.6 \\
\hline & All species & 1.8 & 1.1 & 1.5 & 1.9 & 2.3 & 2.1 & 2.0 & 1.7 \\
\hline \multirow[t]{4}{*}{ c } & Maple-Birch & 2.1 & 1.8 & 1.3 & 0.3 & 1.2 & 0.6 & 1.6 & 0.9 \\
\hline & Oak & 4.7 & 2.2 & 5.2 & 3.9 & 2.4 & 2.6 & 4.1 & 2.8 \\
\hline & Other species & 7.1 & 3.8 & 3.4 & 4.5 & 7.4 & 6.6 & 6.0 & 4.8 \\
\hline & All species & 3.0 & 2.0 & 2.4 & 2.9 & 1.7 & 2.0 & 2.4 & 2.3 \\
\hline \multirow[t]{4}{*}{$D$} & Maple-Birch & 1.1 & 1.8 & 2.4 & 1.7 & 1.5 & 0.5 & 1.7 & 0.7 \\
\hline & Oak & 2.3 & 2.2 & 7.3 & 7.7 & 5.5 & 6.8 & 5.0 & 4.7 \\
\hline & Other species & 1.4 & 3.8 & 0.0 & 0.0 & 2.1 & 8.0 & 0.7 & 2.8 \\
\hline & All species & 1.3 & 2.0 & 3.5 & 5.7 & 2.5 & 4.7 & 2.4 & 4.1 \\
\hline
\end{tabular}

something of the size of trees. For example, the basal area of 500 trees each 2 inches dbh is only 11 square feet. However, 50 trees each 20 inches dbh have a basal area of 109 square feet. Therefore, many small trees must die before the loss of basal area equals that of a single large tree.

During 1927-37 loss of basal area of major species in the undefoliated Meshomasic series was less on tracts whose basal area was less, and differences among sites were less clear than for mortality of stems (trend line, Fig. 5). Average annual loss of basal area was slightly more than 1 percent. In a more recent time, 1959-70 on undefoliated Catlin Wood and Norfolk, annual loss of major species averaged 4.5 and 6.3 percent, respectively. The greater size of trees is reflected in greater loss of basal area in these older stands.

The effect of defoliation on loss of basal area is shown in Fig. 5. On Turkey Hill, defoliated only once during 1957-67, loss of basal area did not differ from that during 1927-37 (Fig. 5, upper). Repeated defoliation on Cox, Reeves and Cabin tracts was accompanied by large increases in loss of basal area, especially on the moist and medium moist sites. In Gay City, defoliated in 1962 and 1967, loss of basal area was less than in the thrice-defoliated Meshomasic series and not greatly different from the trend of 1927-37 (Fig. 5, lower). However, loss of basal area on the dry site, defoliated only in 1962, was less than on the twice-defoliated moister sites.

During 1967-77 the entire Meshomasic series was defoliated twice during 1971-72. Loss of basal area of major species during 1967-77 was less than during 1957-67 and, except for the dry site on Turkey Hill, exhibited less deviation from the trend of 1927-37 than did mortality in 1957-67 (Fig. 6, upper). In the New series, despite one, two or three defoliations during 1970-80, loss of basal area differed little from that in 1927-37 (Fig. 6, lower). Only on the drier sites did loss exceed the trend.

Comparison of tree mortality and loss of basal area (Figs. 3 and 5) indicates that fewer stems died on the Meshomasic series during 1957-67 than died on Gay City during 1959-70, but that loss of basal area on the Meshomasic series was greater than on Gay City. Obviously, larger trees died on the Meshomasic series during 1957-67 than died on Gay City during 1959-70. Similarly, during 1967-77 fewer stems died on the Meshomasic series than on the New series during 1970-80, but loss of basal area was higher on the Meshomasic series. Again, larger trees died. Thus, on older forests the mortality that occurs after defoliation is clearly discernible because large trees die. 


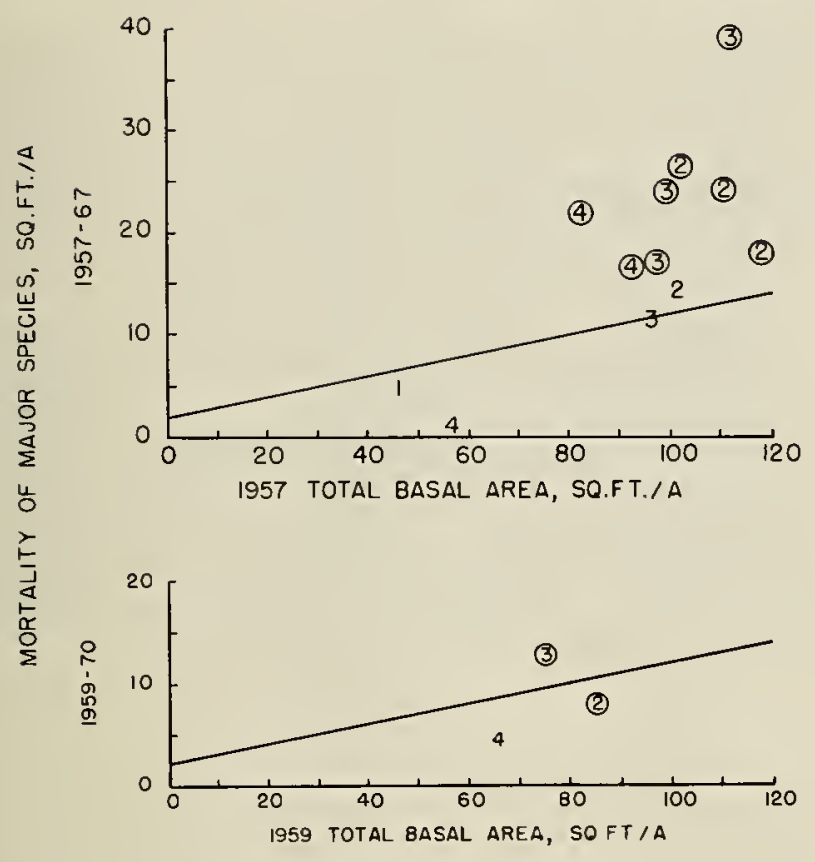

Fig. 5. Periodic basal area loss of major species in tracts with defoliation. The sites are as in Fig. 2. The line is the trend of basal area loss observed during 1927-37 in the Meshomasic tracts. Upper. Meshomasic series 1957-67. Uncircled numbers are from Turkey Hill defoliated in 1964. Circled numbers are from Cox, Cabin and Reeves defoliated in 1961, 1962 and 1963. Lower. Gay City 1959-70. Uncircled 4 is the dry site defoliated in 1962. Circled numbers are the moister sites defoliated in 1962 and 1967.

Losses Among Canopy Trees

Only the larger trees comprise the canopy of the forest. The examination of loss of basal area revealed that on the Meshomasic series some larger trees must have died. How serious are the losses? During a decade without defoliation, 1927-37, mortality of stems in the canopy of the Meshomasic tracts was less where the number of stems participating in the canopy was less and the relation was similar to that in Fig. 2, upper. on the other hand, loss of basal area was nearly constant regardless of total basal area of the trees in the canopy. During a later decade, 1957-67, losses on once-defoliated Turkey Hill were similar to the earlier period, but on Cox, Reeves and Cabin, defoliated three times, losses were greater both in number of stems and basal area. Average mortality of trees from undefoliated canopies was generally 1 percent or less and loss of basal area was less than 2 percent annually. After three consecutive defoliations average mortality of stems in the canopy ranged from 0.9 to 3.6 percent annually and loss of basal

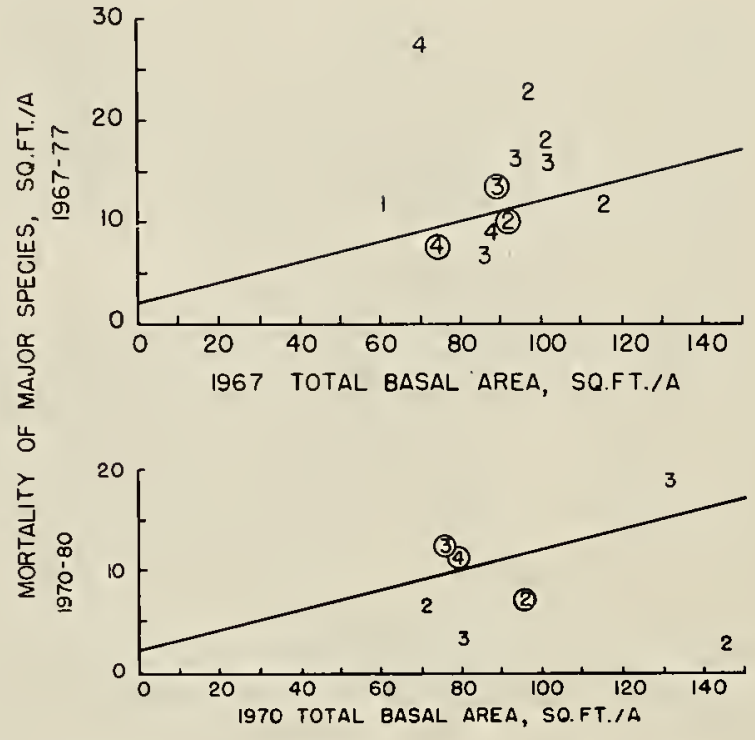

Fig. 6. Periodic basal area loss of major species in tracts with defoliation. The sites are as in Fig. 2. The line is the trend of basal area loss observed during 1927-37 in the Meshomasic tracts. Upper. Meshomasic series 1967-77. All tracts defoliated 1971 and 1972. Cox (circled) severely defoliated in 1971. Lower. New series 1970-80. Catl in wood defol iated 1972; Natchaug defoliated 1972 and 1973; Gay City (circled) defoliated in 1971,1972 and 1973.

area was 0.9 to 3.6 percent. Generally, losses were higher on medium moist and dry sites than on moist sites. In a more recent decade, 1967-77, with two consecutive defoliations, average loss of basal area from the canopy ranged from 0.6 to 4.9 percent annually. In 1967-77 losses on Turkey Hill, defoliated only once during 1957-67 and twice during 1967-77, were generally greater than on the other Meshomasic tracts on all sites, especially on the dry site. Again, there is the suggestion that the amount of mortality in one decade affects the amount in a succeeding decade with defoliation.

The canopy is generally comprised of pole and sawtimber trees, that is, trees with dbh at least 5.6 and 11.6 inches, respectively. At Haddam loss of pole and sawtimber trees increased with increasing defoliation. During 1971-74 on line A, with minimum defoliation, about 19 percent of major species mortality came from the canopy. on line $c$ the canopy contributed 26 percent of mortality while on line $D$, with greatest defoliation, canopy mortality was 40 percent of all major species mortality. Mostly pole-sized trees died. Only 3 percent of the mortality during 1971-74 came from sawtimber trees. 
Thus, it is clear that a single defoliation in a decade has little effect on trees in the canopy, but repeated defoliation increases mortality and the proportion of mortality coming from canopy trees increases, especially among pole-size trees.

\section{Differences Among Species Groups}

Results presented so far are average mortality of all major species present in the tracts examined. However. Table 2 shows that not all species or species groups are defoliated similarly. The mortality among species groups during a decade on undefoliated tracts and on tracts with one, two or three defoliations is tabulated in Table 4. Maples include red and sugar maple; birches include black, yellow and paper birch; oaks include red, black, scarlet, white, and chestnut oak. All are found on the Meshomasic series and all but chestnut oak are found on the New series.

Caks generally had greater mortality of stems than did maples or birches. For example, on Turkey Hill during a decade without defoliation, 1927-37, mortality of oak was greater than that of maple and birch (Table 4,A). During later decades with one or two defoliations, mortality of oak stems was greater than that of maple and birch, but the difference was slight in 1967-77 (Table 4,A). On Cox, Reeves and Cabin tracts (Table 4,B) oak mortality is greater than that of maple and birch during 1927-37 with no defoliation and during 1957-67 with three defoliations. However, during 1967-77 with two defoliations, the percentage of stems dying was less for oak than for other species groups. On undefoliated Norfolk of the New series oak mortality was low and less than maple, birch or other species groups (Table 4,C). On Catlin Wood relatively great oak mortality during 1959-70 without defoliation was followed by light mortality of oak in the succeeding decade with a single defoliation (Table 4,D). On the other hand, at Natchaug, undefoliated during 1959-70, a relatively great mortality of oak was continued during 1970-80 with two defoliations. On the dry site of Gay City (Table 4,F) maple mortality was great but oak mortality was slight with either one or three defoliations. on the moister sites (Table 4,G) oak mortality was high after two defoliations during 1959-70, but lower following the triple defoliation of 1970-80.

Loss of basal area was nearly always greater for oak than for other species groups except on undefoliated tracts. This indicates that in the defoliated stands those oaks that died were large. In contrast, loss of basal area among maples and birches was generally less than proportion of stems lost. Therefore, mortality was removing the relatively small stems of these species.

Even among oaks mortality differed. On the Meshomasic series mortality of defoliated white and chestnut oaks during 1957-77 was always greater than mortality of red, black or scarlet oak (Stephens and Waggoner 1980). on the New series mortality of white oak was greater than red oak during 1959-70 but less than red oak during 1970-80 (Stephens and Hill 1981). Mortality of black and scarlet oaks was slight in both decades.
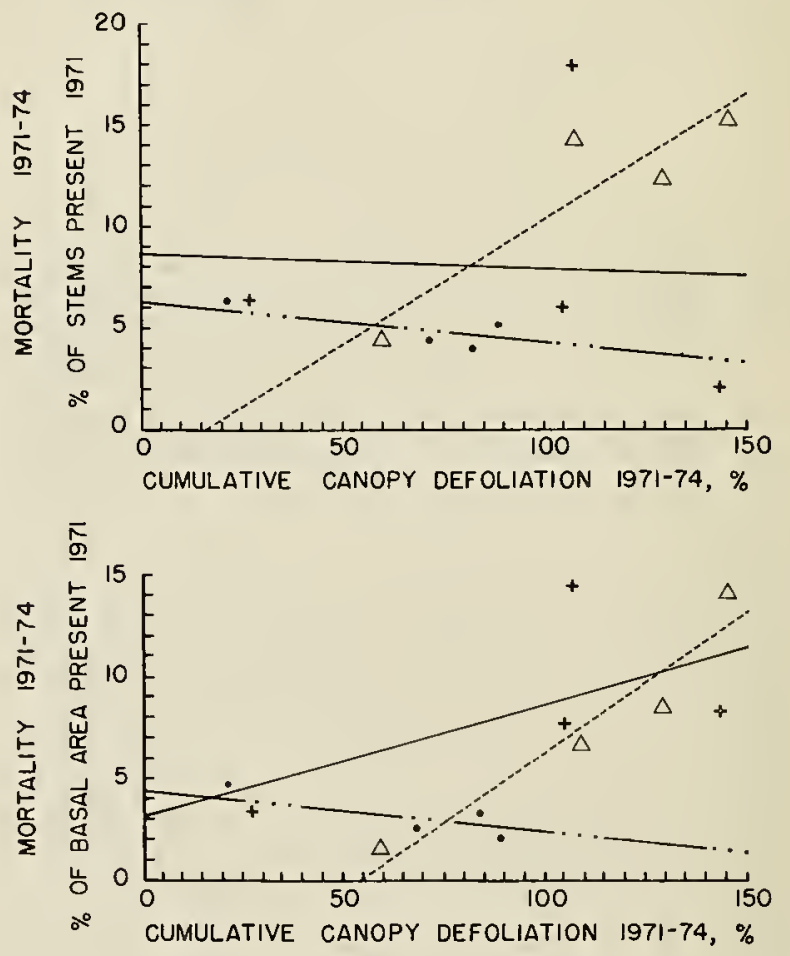

Fig. 7. Mortality of major species groups during 1971-74 in relation to the cumulative canopy defoliation of the group during 1971-74 at Haddam. Average over all sites. Maple-Birch $(\bullet)$, Oak $(\Delta)$, Other major species ( $(+)$. Upper. Mortality during 1971-74 as a percent of stems present in 1971. Lower. Mortality during 1971-74 as a percent of basal area present in 1971.

The relation between cumulative canopy defoliation and mortality of stems and loss of basal area is shown in Fig. 7. Despite increasing removal of the canopy of maple or other species during 1971-74 the mortality 
Table 4. Average annual mortality (percent of total) of major tree species greater than 0.5 inches dbh. Average over all sites.

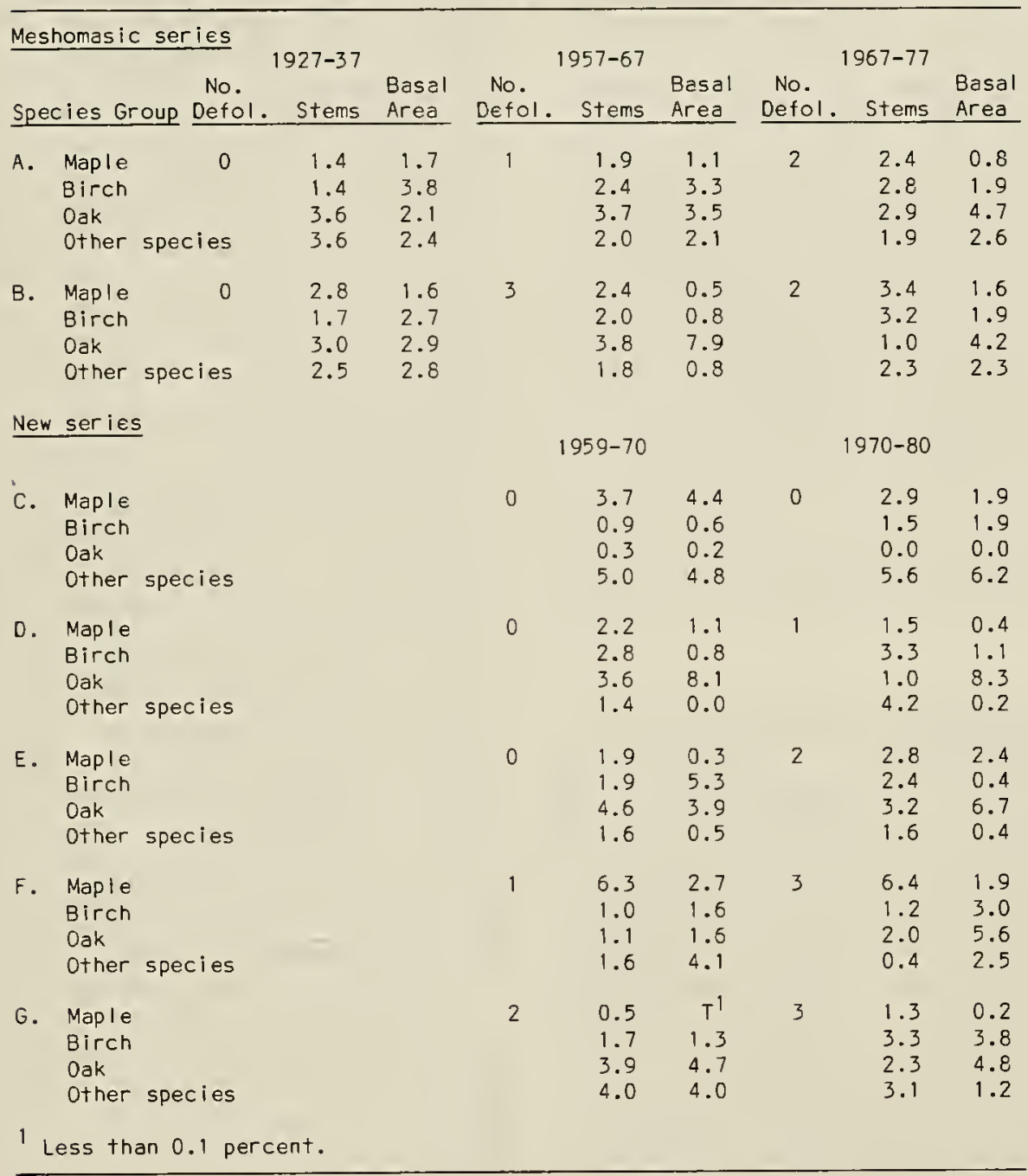

remained relatively constant (Fig. 7 , upper). With oak, however, mortality increased as canopy defoliation of oak increased. Loss of basal area of maple was unaffected by the defoliation of maple. Loss of basal area of oak and other species increased as defoliation increased. Thus, for many species the amount of defoliation affects their mortality.

Oak is a preferred host of many defoliators whereas maple and birch are less attractive. The lesser defoliation of maple and birch may explain the difference in mortality compared to oak. However, the observations prior to 1970 included no known severe defoliation by elm spanworm. This insect does defoliate maple and birch common to the moister sites. Plumb and Friend (1939) reported severe defoliation of red maple and yellow birch during an outbreak of elm spanworm in 1938. They commented that during an earlier outbreak in Massachusetts red maple was almost completely defoliated and yellow birch was defoliated about two-thirds. Complete stripping of red maple for two or three seasons resulted in death of nearly all. However, during the defoliations of the 1970 s elm spanworm was frequently abundant along with gypsy moth. Maples and birches as well as oaks were defoliated. Despite the presence of elm spanworm, observations at Haddam during 1971-72 indicated that oak and other species were generally defoliated more than maples and birches (Table 2). Subsequently, 
on lines B and C, heavily defoliated in 1971 , mortality of maple and birch remained low compared to oak and was confined largely to smaller trees (Table 3).

None of the severely defoliated stands contained many conifers. However, the observations of House (Turner 1963) show the effect of defoliation on conifers. During five years after a single defoliation by gypsy moth, which removed 90 percent or more of their foliage, two-thirds of the hemlock and a fifth of the white pine died. Hemlock mortality was greater for trees in the canopy whereas mostly overtopped white pine died. Eighty percent of hemlock mortality occurred the first year after defoliation. Two-thirds of white pine mortality occurred within two years of defoliation, with about 40 percent during the second year. No hemlock and only one percent of white pine died within five years after being less than 90 percent defoliated.

\section{Mortality in Other Places}

How does mortality in Connecticut's forests compare to other places? Baker (1941) reported tree mortality following gypsy moth defoliation in eastern New England. During 1912-21 about 30 percent of favored food species and 13 percent of un favored species died after one or more defoliation. Thrifty trees seldom died after a single complete defoliation. Once defoliation of individual trees exceeded 20 percent, average mortality quickly rose to about 10 percent in the year after defoliation. However, at the same time mortality of undefoliated trees exceeded 4 percent, more than observed on the Meshomasic series during 1927-37 (Fig. 2). Attack by the twolined chestnut borer and shoestring fungus was often associated with mortality of defoliated trees.

More recently these data were reex anined (Campbell and Sloan 1977). They confirmed the findings of Baker (1941). In addition, they concluded that heavily defoliated trees required 10 years to regain their visual predefoliation condition: dominant trees were less likely to die than subdominants; two successive heavy defoliations were followed by more mortality than was a single defoliation; and losses of trees and basal area after heavy, repeated defoliation were related to the percentage of oak in the stand. They further concluded that during times of little defoliation most defoliation occurred on favored species, but as defoliation increased insects were less selective.
Finally, within each species some trees were consistently more defoliated than others and they were more likely to die.

Turner (1963) summarized the observations of Tierney during 1934-47 in the Connecticut River Valley of Massachusetts. Defoliation by gypsy moth occurred one to eight times during 13 years on 34 areas comprising 2641 acres. In 1947 two-thirds of the area showed 10 to 50 percent mortality, and one-third, 40 to 75 percent mortality. On areas defoliated only once, mortality ranged from 10 to 40 percent, and in some portions, to 75 percent. Similar mortality was observed on repeatedly defoliated areas and. frequently, mortality of oak was great.

Nichols (1968) reported mortality of oaks in Pennsylvania during 1953-66. Twenty defoliators were active, but the oak leaftier was considered most important. Generally, two consecutive defoliations exceeding 60 percent preceded tree mortality, and in a fourth of the cases, three consecutive defoliations occurred. Nearly all dead or dying trees were infested with the twolined chestnut borer. High mortality, 10 percent annually, persisted for only one year after defoliation. Moderate mortality, 5 percent annually, persisted an average of three years. More recently Nichols (1970) reported that an infestation of the oak leafroller had badly defoliated oak stands in northern Pennsylvania. Resulting mortality was typically 30 to 50 percent, but reached 80 to 90 percent in some locations. Most trees required two consecutive defoliations before they died, and tree mortality usually followed three consecutive defoliations. Attack by twolined chestnut borer killed trees apparently weakened by defoliation.

In New Jersey Kegg (1971, 1973) reported oak mortality occurring after defoliation during 1968-70 on the Morristown Naticnal Historical Park and the Newark Watershed. At Morristown after two consecutive defoliations oak mortality ranged from 11 to 39 percent. About one-third of the oak died. Hal $f$ of the dead oaks were poletimber, 6 to 12 inches dbh. Predefoliation mortality was about 6 percent. On the Newark Watershed, 75 to 100 percent defoliated in 1969-70, oak mortality was 27 to 84 percent by 1972 . Predefoliation mortality was 6.5 percent. White and chestnut oak had higher mortality than other oaks. Mortality of birch and maple ranged from 2.7 to 6.6 percent during the same period. In both locations the twolined chestnut borer and shoestring fungus were present in dead or 
dying trees.

In Rhode Island, after repeated defoliation during 1971-73, basal area loss in mixed oak stands was 17 percent compared to 7 percent in similar undefoliated stands (Brown et al. 1979). In oak-pine and mixed hardwood stands mortality was lower, 4 to 7 percent, and there was little difference between defoliated and undefoliated stands. Mortality of white pine was negligible.

The results of defoliation in many eastern hardwood forests are similar. A single severe defoliation has little noticeable longterm effect on the forest. Repeated defoliation is followed by increased tree mortality. Oaks are generally more severely defoliated than other species and their mortality is higher after severe defoliation. White and chestnut oak generally sustain greater defoliation and mortality than do other oaks. In stands not previously severely defoliated mortality after defoliation appears greater than in stands previously defoliated.

Al though repeated defoliation of hardwoods is followed by increased mortality, there is no direct evidence that defoliation actually kills trees. Sycamores are frequently defoliated in late spring by anthracnose, a fungal foliage disease. Old field or roadside black cherry are often severely defoliated by eastern tent caterpillar, yet few seem to die. Indeed, Heichel and Turner (1976) reported that annual defoliation of 50,75 and 100 percent for three successive years on red oak and red maple did not result in the death of any trees. However, severely defoliated trees were apparently weakened. Defoliated trees refoliated, but with fewer and smaller leaves. In succeeding years the amount of new foliage produced each spring was less than on undefoliated trees. Twigs of completely defoliated trees were also susceptible to fungal attack and subsequent twig dieback.

Many of the reports of mortality following defoliation indicated that the shoestring fungus and the twolined chestnut borer were found on dead and dying oaks (Baker 1941; Nichols 1968, 1970; Kegg 1971, 1973). In Connecticut examination of dead and dying oak after defoliation in the 1970s revealed a five-year mortality of 18 to 79 percent (Dunbar and Stephens 1975). More than half of the dead trees examined showed attack by both twolined chestnut borer and the shoestring fungus; 95 percent were attacked by the twolined chestnut borer (Dunbar and Stephens 1975). Attempts to force attack on young red oak trees were successful only on those trees completely defoliated in two consecutive years (Dunbar and Stephens 1976). In another field experiment successful borer attack was induced only on trees that were weakened by partial girdling (Dunbar and Stephens 1976). Thus, weakening of the trees by defoliation or wounding leads to successful attack of oak by the twolined chestnut borer. The shoestring fungus is also better able to attack trees weakend by defoliation (Wargo and Houston 1974, Wargo 1977). Although defoliation may not necessarily kill the trees, it apparently renders them susceptible to other agents that can kill.

Conclusion

What conclusions can I draw from the observations? I cannot predict with certainty the outcome for an individual tree after one or several defoliations. However, a single defoliation of the forest in a decade is not likely to visibly influence mortality. Repeated defoliation will be followed by increased tree mortality, but over a decade the increase is not likely to be more than a doubling. Defoliated oaks will die more frequently than other species and in stands with a high proportion of oak the losses will be greater than where little oak is present. Within a year or two of defoliation mortality will increase temporarily and then subside. The more foliage removed in successive defoliations, the greater will be loss of oak but not of maple and birch. Heavily defoliated forests will exhibit greater mortality the first time than in a subsequent decade with defoliation, apparently because fewer susceptible trees remain. Repeated defoliation will accelerate loss of oak and increase species less susceptible to defoliation, but the forest will not be destroyed. 


\section{$\underline{\text { Literature } \text { Cited }}$}

Baker, W. L. 1941. Effect of gypsy moth defoliation on certain forest trees. J. For. 39: 1017-1022.

Brown, J. H. Jr., D. B. Halliwell and W. P. Gould. 1979. Gypsy moth defoliation: impact in Rhode Island forests. J. For. $77: 30-32$.

Campbell, R. W. and R. J. Sloan. 1977. Forest stand responses to defoliation by the gypsy moth. For. Sci. Mono. 19. $34 \mathrm{pp}$.

Dunbar, D. M. and G. R. Stephens. 1975. Association of twolined chestnut borer and shoestring fungus with mortality of defoliated oak in connecticut. For. Sci. 21: 169-174.

Dunbar, D. M. and G. R. Stephens. 1976. The bionomics of the twolined chestnut borer. p.73-83. In Perspectives in Forest Entomology. J. F. Anderson and $\mathrm{H}$. K. Kaya, (ed.) Academic Press, NY. 428 pp.

Heichel, G. H. and N. C.Turner. 1976. Phenology and leaf growth of defoliated hardwood trees. p.31-40. In Perspectives in Forest Entomology. J. $\vec{F}$. Anderson and $\mathrm{H}$. K. Kaya (ed.) Academic Press, NY. 428 pp.

House, W. P. 1952. Appraisal of damage by the gypsy moth in New England 1922-52. USDA, Agr. Res. Admin., Bur. Ent. Plant Quarantine, Gypsy Moth Control Proj. 22 p. (mimeo).

Kegg , J. D. 1971. The impact of gypsy moth: repeated defoliation of oak in New Jersey. J. For. 69:852-854.

Kegg, J. D. 1973. Oak mortality caused by repeated gypsy moth defoliations in $\mathrm{New}$ Jersey. J. Econ. Ent. 66:639-641.

Nichols, J. O. 1968. Oak mortality in Pennsylvania - a ten year study. J. For. $66: 681-694$.
Nichols, J. O. 1970. Oak mortality. Penn. Dept. Forest and Waters, Harrisburg. Forest Pest Rep. No. 43. 2 pp.

Plumb, G. H. and R. B. Friend. 1939. An outbreak of the elm spanworm in Connecticut, 1938. p. 98-102. In Britton, W. E., Connecticut State Entomologist Thirtyeighth Report. The Conn. Agr. Expt. Sta., New Haven. Bull. 428.

Stephens, G. R. 1971. The relation of insect defoliation to mortality in Connecticut forests. The Conn. Agr. Expt. Sta., New Haven. Bul1. 723. $16 \mathrm{pp}$.

Stephens, G. R. and D. E. Hill. 1971. Drainage, drought, defoliation and death in unmanaged woodlands of connecticut. The Conn. Agr. Expt. Sta., New Haven. Bull. 718. $50 \mathrm{pp}$.

Stephens, G. R. and D. E. Hill. 1981. Changes during twenty years in four undisturbed and unmanaged connecticut woodlands. The Conn. Agr. Expt. Sta., New Haven. Bull. 799. (in preparation).

Stephens, G. R. and P. E. Waggoner. 1980. A half century of natural transitions in mixed hardwood forests. The Conn. Agr. Expt. Sta., New Haven. Bull. 783. 43 pp.

Turner, N. (ed.) 1963. Effect of defoliation by the gypsy moth. The Conn. Agr. Expt. Sta., New Haven. Bull. 658. 30 pp.

Wargo, P. M. 1977. Armillariella mellea and Agrilus bilineatus and mortality of defoliated oak trees. For. Sci. 23: 485-492.

Wargo, P. M. and D. R. Houston. 1974. Infection of defoliated sugar maples by Armillaria mellea. Phytopath. $64: 817-822$. 
Common and scientific names of trees, insects and fungi mentioned in this report. TREES

Birch, black -- Betula lenta L.

- paper -- B. papyrifera Marsh.

- yellow -- B. alleghaniensis Britton

Cherry, black -- Prunus serutina Ehrh.

Hemlock -- Tsuga candensis (L.) Carr.

Maple, red -- Acer rubrum L.

, sugar $\overline{--A}$. Saccharum Marsh.

Oak, black -- Quērcus velutina Lam.

- chestnut -- Q. prinus L.

, red -- Q. rubra L.

, scarlet-- Q. coccinea Muenchh.

, white -- Q. alba L.

Pine, white -- Pinus strobus L.

Sycamore -- Platanus occidentalis L.

\section{INSECTS}

Eastern tent caterpillar -- Malacosoma americanum F.

Elm spanworm -- Ennomos subsignarius Hbn.

Fall cankerworm -- Alsophila pometaria Harris

Gypsy moth -- Lymantria dispar L.

Oak leafroller -- Archips semiferanus WIk.

Oak leaftier -- Croesia semipurpurana Kearf.

Spring cankerworm -- Paleacrita vernata Peck.

Twolined chestnut borer -- Agrilus bilineatus Web.

\section{FUNGI}

Anthracnose, sycamore -- Gnomonia platani Edg.

Shoestring fungus -- Armillariella mellea (Vahl. ex Fr.) Karst 

$A \leqslant 2 \leqslant$ University of Connecticut Libraries

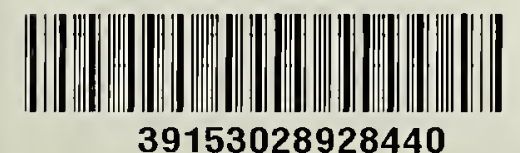


